\title{
El Von Bertalanffy and Mortality from Fish Kurau (Polynemustaenitatus) of The Catch Fisherman in Waters Bunyu
}

\author{
Gazali Salim $^{1, *)}$, Pius Bae Kelen ${ }^{2)}$
}

\begin{abstract}
The aim of the research are analyzing the growth model using Von Bertalanffy and mortality in Polynemus taeniatus. Research methods a descriptive kuantitatif by using the case study. Determining the location of sampling are purposive sampling, by following fishing boats Drift Gill Net. Sampling funded every two weeks once upon a huge tide. Data collection techniques using survey. Data retrieval in the form of total length and total weight. The samples from 4 (times) for 3 months. Each sample taking having vulnerable time between 2-5 day in bunyu waters. Research results use the model von bertalanffy obtained maximum length fish kurau (p.taeniatus) is $156,794 \mathrm{~cm}$ in 349 days. Value $\mathrm{K}$ of 0.0364 $\mathrm{cm}$. Value To of $-1,2819 \mathrm{~cm}$. The results of data processing of fish catch kurau (P.taeniatus) obtained by mortalitas natural 0,435; mortalitas total of 1.121 ; mortalitas arrest of 0,6859 ; the exploitation of fish kurau 0,61.
\end{abstract}

Keywords-Growth, Model Von Bertalanffy, Mortality, Polynemustaeniatus, Bunyu Waters

\section{INTRODUCTION}

I ndonesia has one of the having biological resources the sea abounding, because indonesia has tropical climate with the temperature the sea who warm enough for daily necessities and habitat of ecosystem for biota waters. Waters has a temperature of warm so as to cause habitats ecosystem be used as the ecological preference for species of of especially kurau that is in the waters bunyu. This is in accordance with the results of the study of Salim and Kelen (2017) [1] explained that based on identification of the fish use drift gill net obtained as many as 12 species yangada in the waters bunyu which is a otek, stingrays, fish selangi, fish machete, snapper white, fish mackerel, fish white sand sharks, fish gulamah, fish arut-arut, fish manyung, red fishes and fish kurau.

Many species of fish on the areas of waters Bunyu, made waters who was in the area a meeting between the pacific ocean and sea sulawesi as waters in accordance with their condition decent for life and many the fishermen catch fish over the areas of waters bunyu island, especially fishermen drift gill net that is the catch thing is fish kurau ( $P$. taenitatus). Based on the results of the research from Salim and Kelen (2017) [2] look at of composition of the fish fishermen used a get drift gill net the main catch of fish kurau (P.taeniatus) as much as $56,04 \%$ with weight about 281,2 $\mathrm{kg}$; Results fish catch a side (HTS) as much as $29,57 \%$ with weight about $148,4 \mathrm{~kg}$ and the catch discard of $14,39 \%$ with weigh as much as $72,2 \mathrm{~kg}$.

${ }^{1}$ Lecture Department Management Resources of Waters

${ }^{2}$ College Student Department Management Resources of Waters

FPIK University of Borneo Tarakan (UBT) Kampus Pantai Amal Gedung E, Jl.Amal Lama No.1,Po. Box. 170 Tarakan KALTARA. ${ }^{(1)}$ HP.081346583552,

*Corresponding author : axza_oke@yahoo.com

In addition also according to Salim and Kelen (2017) [3] explained that fish p.taeniatus having economic value look at from the price of a high there are two composition the composition of meat is approximately rp.150,000, - / kg and composition ose (bubbles its belly) around rp.5.200.000, -per kilogram. The growth of fish p.taeniatus have been over do by Salim and Kelen (2017) [4] where growth allometri good male and female is allometri negative, where the form of the body a male fish the average thin and bodily form a female the average fat. Research has been done on the P.taenitus is research on study the population with growth allometri and codition index fish of kurau (Polynemus taenitus) acquired in bunyu island waters, north borneo (Salim and Kelen,2017) [5]; Analysis identification the composition catch used a get jarring gills drift (drift gill nett) around island bunyu, kalimantan the north (Salim and Kelen, 2017) [6]; Analysis Growth and Age Structure Fish of Nomei (Harpodon nehereus) In Sea Jauta Waters Tarakan City Firdaus (2013) [7].

However research on growth von analysis model bertalanffy and mortalitas of fish kurau (P.taeniatus) of fish catch in waters bunyu, has rarely been implemented.Research purposes and analyze growth use the model von bertalanffy and analyze mortalitas fish kurau (P. taeniatus) of fish catch derived from bunyu waters.

\section{PROCEDURE FOR PAPER FORMATTING}

\section{Time and place}

Study was conducted for approximately two monthsDecember 2016 until January 2017, begun when collecting first sampling to finish the sampling held in waters off bulungan bunyu district, Province of Borneo North.

\section{Tools and materials}

Instrument in use the research is fishing vessels used a catch gill nets drifting ( drift gill net ), gps, digital camera, the meter and weight.Material used the research is sample kurau fish ( p.taeniatus ); table tides ; book of idenfication taxonomy fish.

\section{The methodology}

The methodology use the methodology descriptive in kuantatif by using the method case study.

\section{The determination of procedure research Locations the sample}

Techniques and methods of the using "purposive sampling", based on the fishing vessels used a catch drift gill net.The sample kurau fish in every two weeks for based on the tide large.The data on the ground in doing some 4 times looping (2 months). 


\section{A design study}

Methods and engineering in data collection research using design survey.Fish catch kurau (P.taeniatus) derived from catch fishermen using jarring gills drifting (drift gill net) in waters ofbunyu, district bulunganBorneo Northern Province.The samples from 4 ( times ) for 3 months.

The sample collection done by following fishermen jarring gills drift (drift gill net who made island bunyu for areas of the fish (fishing ground). Each sample taking having susceptible time between 2 to 5 days in waters bunyu, KabupatenBulungan, North Borneo. Fish at gunpoint by by jarring gills drift (drift gill net), in measuring long total and a total weight.The data in extract of the total length and a total weight.

\section{EQUATIONS}

\section{Growth absolute ( absolute )}

Model von bertalanffy parameter growth using formulas according to Von Bertalanfy (Sparre \& Venema, 1999) with equation as follows :

$$
\mathbf{L t}=\mathbf{L} \infty\left(1-\mathrm{e}^{-\mathbf{k}(\mathbf{t}-\mathbf{0})}\right)
$$

Description :

$\mathrm{Lt}=$ long fish nomei at age $\mathrm{t}$ (unit time)

$\mathrm{L}_{\infty}=$ maximum length fish Kurau theoretically (Lenght asimtotik)

$\mathrm{K}=$ the fish growth kurau (per unit time)

$\mathrm{t}_{0}=$ age teortis fish kurau at length equal to zero

\section{Structure age}

To analyze structure, used method of shifting class mode of with a model Von Bertalanffy in Sparre,et al (1999) namely:

$$
\begin{array}{lll}
(\Delta \mathbf{L} / \Delta \mathbf{t}) & =\left(\mathbf{L}_{2}-\mathbf{L}_{1}\right) /\left(\mathbf{t}_{2}-\mathbf{t}_{1}\right) \\
\mathbf{L}_{(\mathbf{t})} & =\left(\mathbf{L}_{2}+\mathbf{L}_{1}\right)
\end{array}
$$

Description :

$\Delta \mathrm{L} / \Delta \mathrm{t} \quad=$ Growth relative

$\Delta \mathrm{L} \quad=$ Length fish

$\Delta \mathrm{t} \quad=$ Interval time

$\mathrm{L}_{(\mathrm{t})} \quad=$ Length average modus

Value $\mathrm{L}_{(\mathrm{t})}$ dan $(\Delta \mathrm{L} / \Delta \mathrm{t})$ obtained a regression linear:

$\mathbf{Y}=\mathbf{a}+\mathbf{b x}$

Description :

$\mathrm{a}=\left(\left(\sum y / n\right)-\left(\mathrm{b}\left(\sum x / n\right)\right)\right)$

$\mathrm{b}=\left(\mathrm{n} \sum(x y)-\left(\sum x\right)\left(\sum y\right)\right) /\left(\left(\mathrm{n} \sum x^{2}-\left(\sum x\right)^{2}\right)\right.$

The average value length of a mode of length of this method to count lenght asimtotik ( $\mathrm{L} \infty)$ is a / b , while the coefficients growth $(\mathrm{k})$ is $-\mathrm{b}$.

Age theoretical a fish on when long equal to zero might be expected separately use equation empirical (Pauly in Sparre and Venema, 1999);

$$
\log \left(-t_{0}\right)=0,3922-0,275(\log \operatorname{L} \infty 1,038(\log K)
$$

Description :

$\mathrm{L} \infty \quad=$ Length asymptote fish kurau $(\mathrm{cm})$

$\mathrm{K}=$ The coefficients growth rate fish kurau

$\mathrm{T}=$ Age theoretical fish kurau at the time long equal to zero (in years)

\section{Mortality}

Mortality natural (M) due to allegedly with using formulas empirical Pauly (1984) :

$\log \quad M=-0,0066-0,279 \log L \infty+0,6543 \log K+0,4634$ $\log \mathrm{T}$

Mortalitas total ( $\mathrm{Z}$ ) due to allegedly with using formulas Beverton \&Holt (Sparre \&Venema, 1999) as follows:

$$
\mathrm{Z}=\mathrm{K} \cdot\left[\frac{\mathrm{L}_{\infty}-\bar{L}}{\bar{L}-L^{\prime}}\right]
$$

Mortality Catching (F) as follows :

$\mathrm{F}=\mathrm{Z}-\mathrm{M}$

Rate of The exploitation (E) allegedly using formula Baranov (Sparre \& Venema, 1999) as follows:

$$
E=\frac{F}{Z}
$$

\section{FIGURES AND TABLES}

\subsection{Structure age}

Structure age at fish P.taeniatus having to scatter class as many as 10 classes in processing von bertalanffy model.The results to scatter class was the number of species fish kurau found during 4 times the sample collection.To scatter class the most found on the size the average length of about 79,4 $\mathrm{cm}$ and $116 \mathrm{~cm}$ with 4 sample. The smallest size of fishes kurau by one sample with size of 59,8 centimeters and of the largest size of fishes kurau as much as two sample with size of $140,2 \mathrm{~cm}$. The following is to scatter class of a structure age based on of the catch the number of species fish kurau (P. taeniatus).

Techniques and methods to analyse model structure age in a shift class the model integrated in the model growth von bertalanffy, so that gathered in formula equation value regression which are $(y=-0.036 x+5.707)\left(R^{2}=0,516 ; r=\right.$ 0,718 ). In figure 2 elaborate about age structure fish P.taeniatus there were graphs the regression equation is linear.The regression equation is linear in the picture to explain that the regression line is linear when exposed to the axis $\mathrm{X}$, hence the regression line was figures stating that lenght fish from P.taeniatus already have speed zero (see axis Y) by having maximum length of fish worth p.taeniatus $156,794 \mathrm{~cm}$.Charts the regression equation is linear explain that the increasingly increasing fish age hence the speed of growth of fish will decrease so causing long growth of fish will suffer constant. 


\section{Class Age Structure}

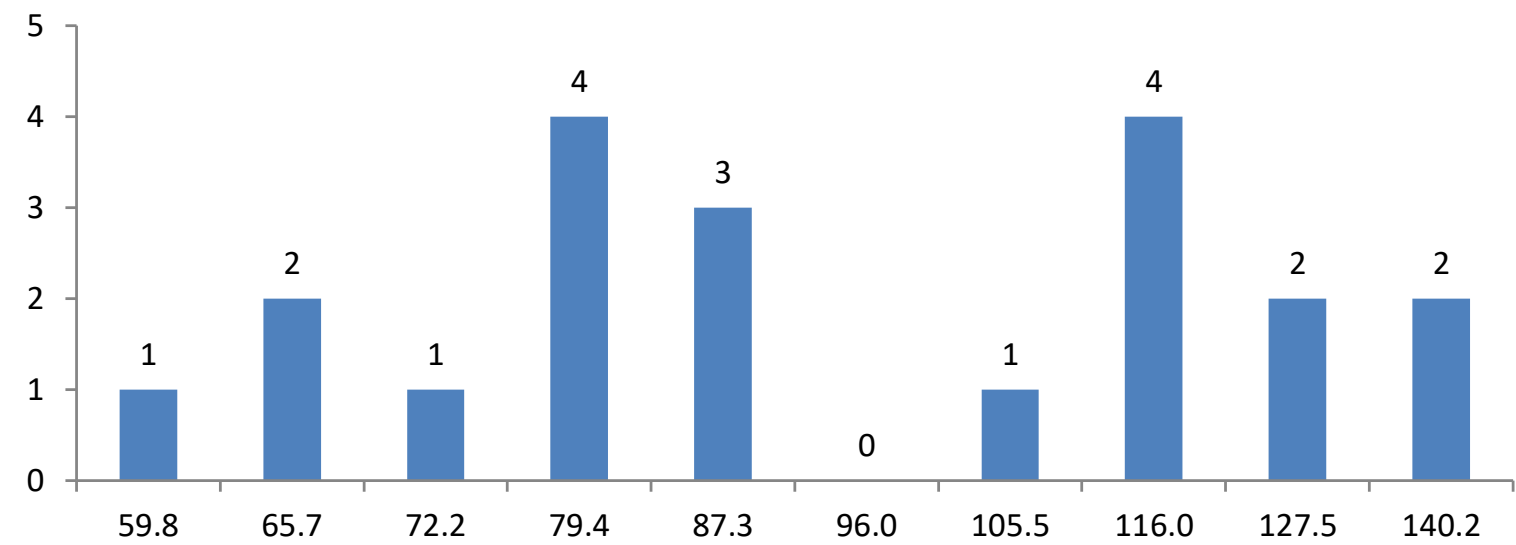

Fig 1. To scatter classes in structure age based on fish catch kurau

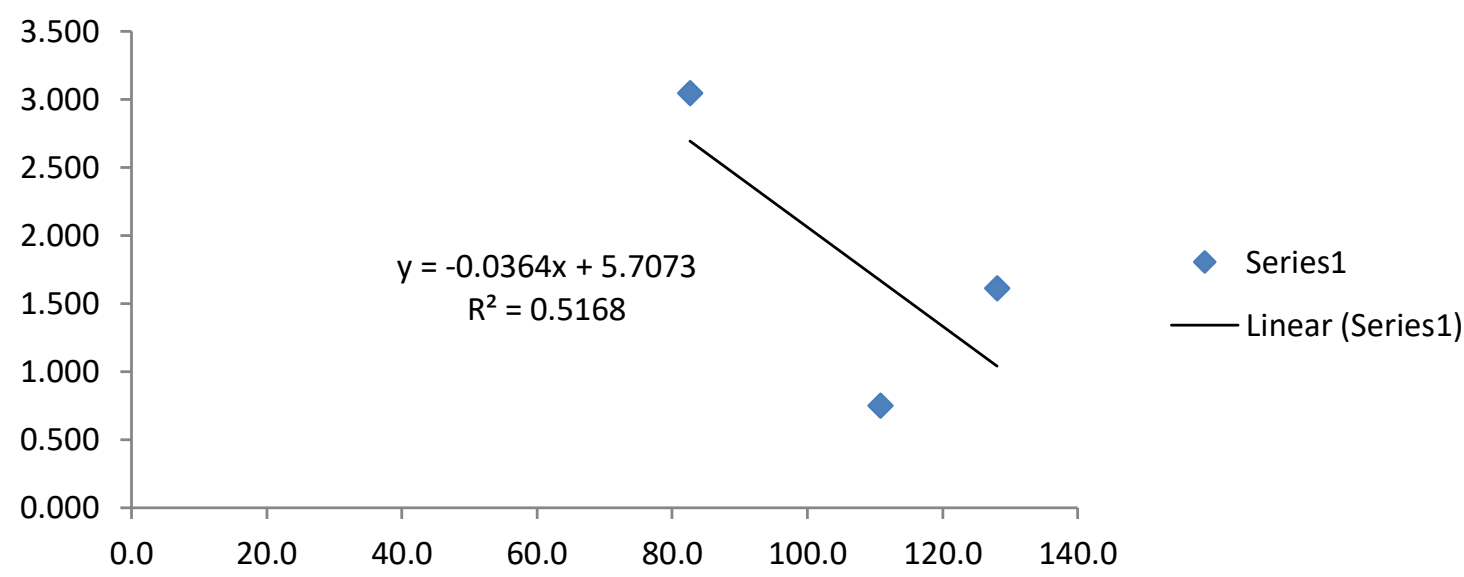

Fig 2 .Age structure fish kurau (P. taeniatus)

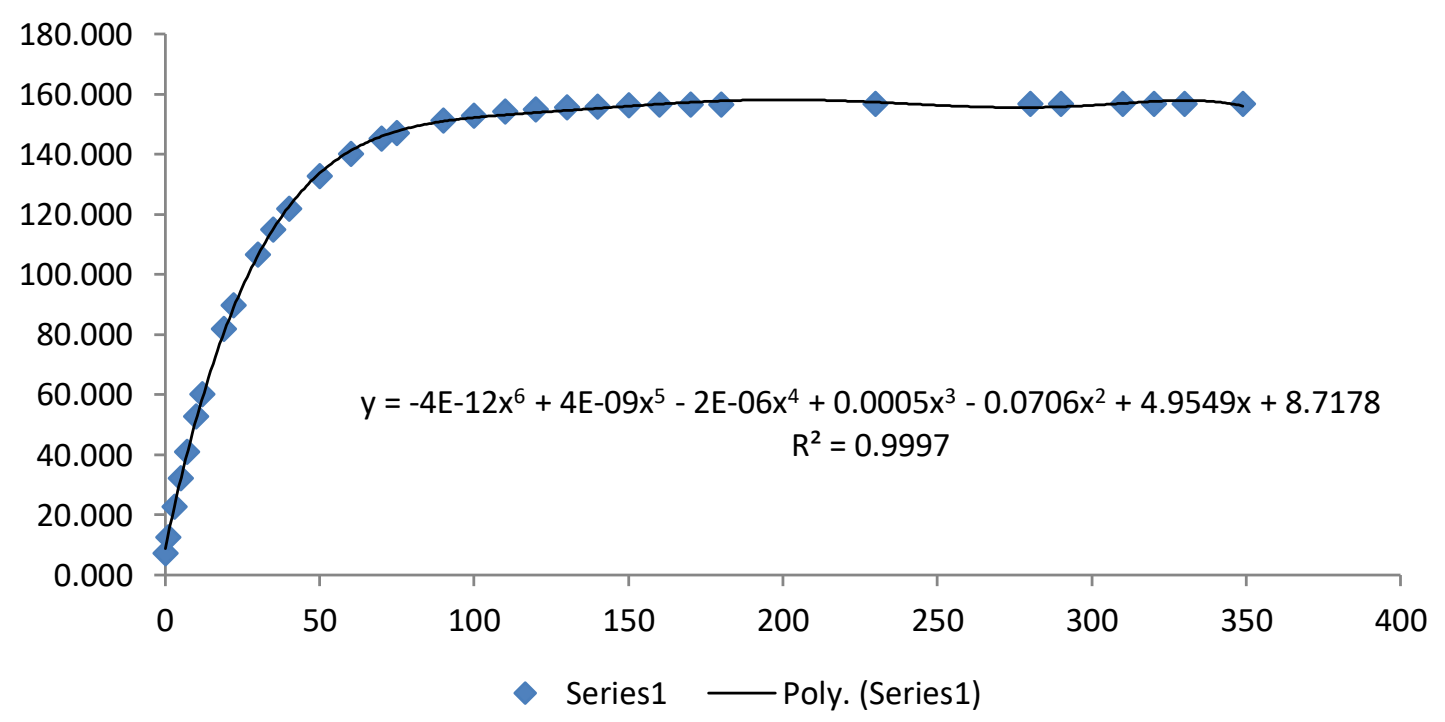

Fig 3. Model von bertalanffy fish kurau (P.Taeniatus) 
Mortality and Rate of Exploitation

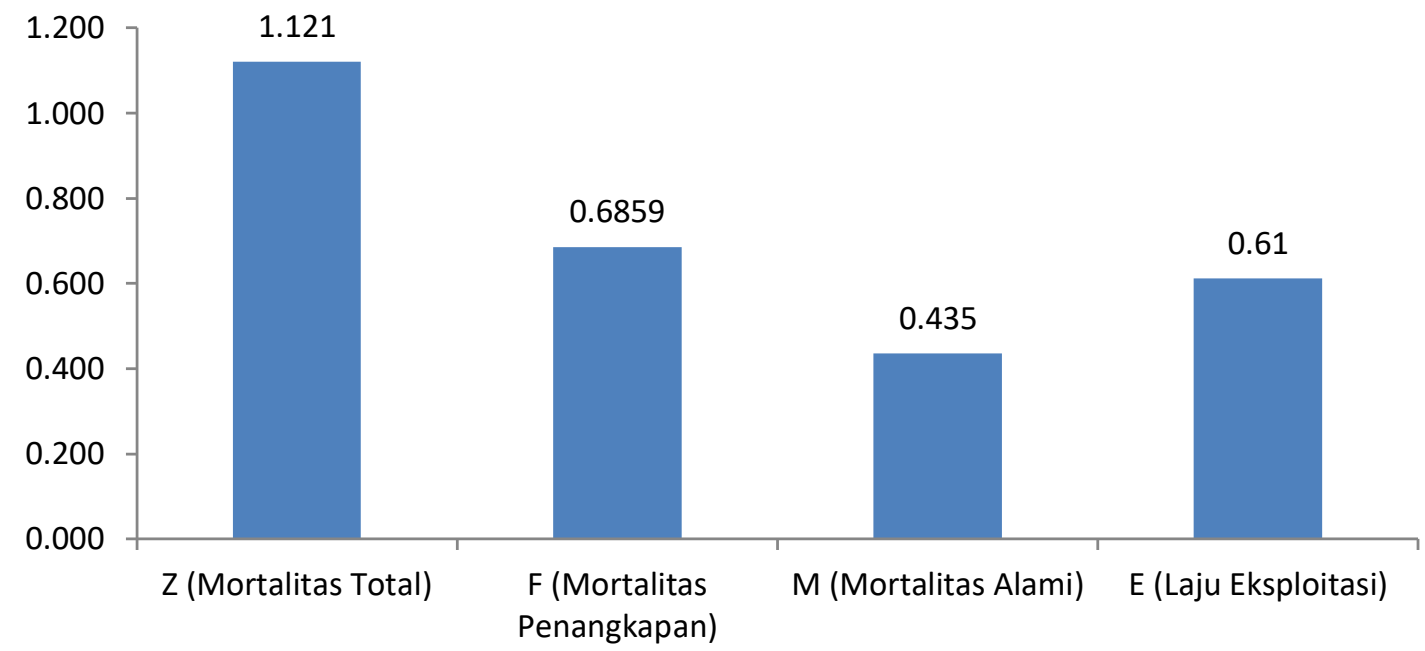

Fig 4. Mortality and Rate of Exploitation fish of Kurau (P. taeniatus)

The speed of growth if fish reached the point of zero (constant) then fish has not experienced growth lenght (lenght maximum). This is consistent with the value of the strong correlation worth 0,718 . Correlation value this explains that when increase old the fish so rapidity of growth will be more low, and when rapidity of growth fish reach a point zero then growth fish is not experienced growth again (lenght maximum).

\subsection{Model Von Bertalanffy}

In figure 3 of what the models von bertalanffy fish kurau ( $\mathrm{p}$. Taeniatus ) explained that, on the $\mathrm{x}$ axis is old the fish kurau and the $\mathrm{y}$ axis is long total of fish kurau.The picture describing on equation polynomial orthogonal type 6 in get as follows: $y=-4 \mathrm{e}-12 \times 6+4 \mathrm{e}-$ $09 \times 5-2 \mathrm{e}-06 \mathrm{x} 4+0.000 \times 3-0.07 \times 2+4.954 \mathrm{x}+8.717$ with the $\mathrm{r} 2=0.999$ and correlation value of 0.999 .

A picture model von bertalanffy explained that growth early since fish P.taeniatus entered the stage larvae already has growth by use the model von bertalanffy is as much as $7.148 \mathrm{~cm}$. Growth fish kurau including growth fast enough where growth in when larvae to juvenile growth fast enough to age 90 days to the growth of long as $151,140 \mathrm{~cm}$.

In addition the growth of fish kurau growth slowdown at the age of 100 days to the size of a 152,865 $\mathrm{cm}$ to reach growth maximum $(\mathrm{L} \infty)$ on the size 156,794 $\mathrm{cm}$ to the days of about 349 days. The average speed of the growth of fish P.taeniatus $0.0364 \mathrm{~cm}$ per day.

\section{3 .Mortalitas fish kurau (P. taeniatus)}

Mortality on fish kurau there are three parts those are mortalitytotal, mortality the cathcing and mortality natural.The influence of mortalitas an impact on the rate of exploitation.In figure 4 explain who mortality value and the exploitation of fish P.taeniatus. In figure 4 describing on the results of data processing based on fish catch p.taeniatus obtained mortality natural of 0,435 / year; mortality total of p.taeniatus of 1.121 /year and mortalitas because the results of the fish catch fish kurau obtained mortalitas arrest of 0,6859 / year.In addition also berdarakan on the results of data processing derived of the catch fishermen fish kurau obtained the rate of exploitation fish kurau of 0.61 / year.

\section{CITATION}

Citations are made as: [1], [4]-[5]. Citations are made as: [2], [4]-[5]. Citations are made as: [3], [4]-[5]. Citations are made as: [4], [4]-[5]. Citations are made as: [5], [4]-[5]. Citations are made as: [6], [4]-[5]. Citations are made as: [7], [1].

Citations are made as: [8], [6].

Citations are made as: [9], [7]-[8].

Citations are made as: [10], [7]-[8].

Citations are made as: [11], [7]-[8].

Citations are made as: [12], [7]-[8].

Citations are made as: [13], [6].

Citations are made as: [14], [7]-[8].

Citations are made as: [15], [7]-[8].

Citations are made as: [16], [7]-[8]. 


\section{CONCLUSION}

Growth use the model von bertalanffy obtained long maximum is $(\mathrm{L} \infty)$ as much as $156,794 \mathrm{~cm}$ with advanced about 349 day.An average speed growth p.taeniatus of $0,364 \mathrm{~cm}$ per day. Growth at the age of zero years reached $7,148 \mathrm{~cm}$. Mortality total $(\mathrm{z})=1,121$ per year, mortality natural $(\mathrm{M})=0,435$ per year and mortality cathing $(\mathrm{F})=$ 0,6859 per year.The rate of exploitation $(E)=0.61$ per year.

\section{REFERENCES}

[1] Firdaus, M; Salim G; Ermawaty; Maya I. A; Syahrun. 2013. Analisis Pertumbuhan dan Struktur Umur Ikan Nomei (Harpodon nehereus) Yang Terdapat Di Perairan Juata Laut Kota Tarakan. (Jurnal Akuatika, Volume 4 Nomer 2 Bulan Oktober Tahun 2013).

[2] Pauly, D. 1984. Fish Population Dynamics In Tropical Waters : a manual for use with programmable calculators. ICLARM.Studies and reviewes) Paperback-1984.

[3] Pauly, D. 1980. A Selection of Simple Method for the Assesment Tropical Fish Stock. FAO. Fish Tech. New York.

[4] Salim G dan Kelen P. B. 2017. Study Population With Growth Allometri And Codition Index Fish Of Kurau (Polynemustaeniatus) Acquired In Bunyu Island Waters, North Borneo. ISBN : 978.602.60736-5-5. Procceding $10^{\text {th }}$ ADRI 2017 International Multidiciplinary Conference and Call For Paper. Batam, March3-4, 2017.

[5] Salim G dan Kelen P B. 2017. Analsis Identifikasi Hasil Komposisi Tangkapan Menggunakan Alat Tangkap Jaring Insang Hanyut (Drift Gill Nett) Di Sekitar Pulau Bunyu Kalimantan Utara. Jurnal Harpodon Borneo Volume 10 No 1 Bulan April 2017. ISSN.2087-121X. Website :http://jurnal. borneo.ac.id/ index.php/harpodon/index

[6] Sparre, P., Siebren C dan Venema. 1999. Introduksi Pengkajian stok Ikan Tropis. Pusat Penelitian dan Pengambangan Perikanan. Badan Penelitian dan Pengembangan Pertanian, Jakarta, $438 \mathrm{hlm}$.

[7] Sparre, P.E., Ursin and S.C. Venema. 1989. Introduction to tropical Fish Stock Assessment. Part I Manual. FAO Fisheries Technical Paper 306/1.

[8] Sparre, P.E., Ursin and S.C. Venema. 1999. Introduksi Pengkajian Stok Ikan Tropis. Buku Manual I. FAO. 